\title{
Public engagement and institutional usage of Facebook in legislative assemblies from the Southeast Region of Brazil
}

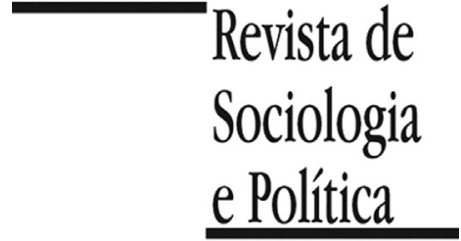

DOI 10.1590/1678-987320287603EN

\section{Cristiane Brum Bernardes' \\ ${ }^{I}$ Mestrado Profissional em Poder Legislativo, Centro de Formação, Treinamento e Aperfeiçoamento da Câmara dos Deputados, Brasília, DF, Brazil.}

KEYWORDS: Legislatures; Legislative Assemblies; Facebook; Social Media; Public Engagement.

\begin{abstract}
Introduction: In a context of intensification of interactivity, hyperconnectivity and mobility, and expansion of the possibilities of digital contact between legislative institutions and citizens, this study compares how the four legislative assemblies of the Southeast region of Brazil use the institutional profiles created on Facebook. The objective is to understand how the process of public engagement, as conceptualized by Leston-Bandeira (2014), is being carried out by the legislative houses on this platform. Materials and Methods: The recollection of empirical data on the profiles of the legislative assemblies of São Paulo (ALESP), Minas Gerais (ALMG), Rio de Janeiro (ALERJ) and Espírito Santo (ALES) was held between August 2018 and October 2019. The following techniques were applied: 1) in-depth interviews with the managers of digital communication of the houses and 2) comparative analysis of publications and comments on Facebook in the period between August 2018 and January 2019. Profile data were collected through the Netvizz application and later analyzed in Excel. The interviews were conducted between August and December 2018 and in October 2019 in person or via Skype / WhatsApp video. Results: Comparative data reveal that the @assembleiademinas profile made more intense use of Facebook in the period analyzed, despite having fewer followers than the profiles of ALERJ and ALESP. In addition to posting more, ALMG's profile achieved more interactions with citizens, especially through reactions to some posts made in October and December 2018. Of the four assemblies analyzed, ALES' profile had the lowest quantitative reach, in number of users who interact, both in reactions and comments. ALMG has the profile that received most reactions per post, while ALESP received more comments per post in the period. Discussion: The most general conclusion is that the four legislative houses analyzed fail to monitor the contributions of internet users and promote a more dialogical interaction with them, focusing on the levels of information, understanding and identification of the process of public engagement. There is, therefore, a difficulty in including aspects of participation and intervention in political decision-making in the dynamics of social media. To a last extent, by not taking advantage of the dialogical potential of networks, legislative assemblies waste opportunities for engagement with the citizen and intensify their distance from society.
\end{abstract}

Received in November 26, 2019. Approved in September 28, 2020. Accepted in October 20, 2020.

\section{Introduction ${ }^{1}$}

${ }^{1}$ We thank the comments and suggestions of the anonymous reviewers of the Revista de Sociologia e Política.
I $n$ the institutional and political scenario of the 21 st century, any analysis or study of legislatures needs to consider that politicians, citizens, governments and civil society organizations are engaged in the use of different digital platforms, with a specific interest in influencing political decisions. In this sense, the aspects of public engagement, according to the concept of LestonBandeira (2014), can find in digital platforms a means of facilitation. This paper aims to analyze this process and practices that legislative houses adopt in social media, specifically the content shared by the institutions and the managers' considerations about the activity.

It is worth remembering that, despite being a concept still in dispute, "Digital Democracy" already finds some minimum points of consensus among researchers in the area (Gomes 2016; Mendonça, Pereira \& Filgueiras 2016; Silva, Sampaio \& Bragatto 2016). In a very broad sense, Digital Democracy is a concept and a political process that includes different communicative practices and involves technologies, digital platforms and devices in political action, with 
the aim of expanding the autonomy of political actors and equality between them in decisions, institutional or not (Gomes 2011; Mendonça 2016).

In the last decade, the mobility and hyperconnectivity of portable devices have changed the way users relate to each other and the Internet. Social media applications and platforms bring users together around preferences, habits and connections and lead political actors to invest in these new modalities of interaction. In Jensen's words (2013), the internet has moved from the information age to the era of communication and network production in the last decade, with the intensification of interaction between users.

This paper focus on the use Brazilian subnational parliaments were making of "social networking sites" (boyd \& Ellison 2008), that is, internet services that allow individuals to: 1) build a public profile; 2) articulate a list of other users with whom they want to connect; and 3) browse their contact list and the list of the other ones in the system. Based on other studies already conducted on the use of ICTs by Brazilian parliaments (Barros, Bernardes \& Rodrigues 2015; Barros, Bernardes \& Rodrigues 2016; Braga 2008; Mendonça \& Pereira, 2016), it analyzes the use of the institutional profile on Facebook by the four subnational parliaments located in the Southeast Region: Legislative Assembly of Minas Gerais (ALMG), Legislative Assembly of the State of São Paulo (ALESP), Legislative Assembly of Espírito Santo (ALES) and Legislative Assembly of the State of Rio de Janeiro (ALERJ). It is important to highlight that the focus is the institutional profiles of the assemblies instead of analyzing the profiles of individual political actors, the parliamentarians.

The comparison between the assemblies of the same region of the country allows us to evaluate whether there are regional differences that can justify different approaches in the use of social media. It should be emphasized that, despite the variety of studies on Brazilian national legislative houses (Senate and House of Representatives), there are still few studies on the institutional dynamics of state or even local legislatures, despite the possibility of comparative studies.

The Southeast Region was chosen because it brings together the largest population in the country, besides sustaining relevant indexes of internet access. According to the Brazilian Geographical and Statistical Institute (IBGE 2018), the three most populous Brazilian states are in the region: São Paulo (46 million), Minas Gerais (21.2 million) and Rio de Janeiro (17.2 million). Espírito Santo has 4 million inhabitants. With 88.4 million inhabitants, the Southeast has more than $42 \%$ of the Brazilian population. Regarding the percentage of internet use in Brazil, the state research made in 2017 (PNAD 2017) showed that $81.1 \%$ of households in the region use the Internet, while the national index was $74.9 \%$.

The largest constituencies are also in the region: São Paulo has $22.5 \%$ of Brazilian voters, Minas Gerais has $10.6 \%$ and Rio de Janeiro 8.4\%. Together with Espírito Santo (1.9\%), the Region accounts for $43.4 \%$ of the votes in the country. Since the number of elected to the Legislature is proportional to the population of the electoral district, these states hold the largest benches in the House of Representatives and the largest state legislatures in number of parliamentarians: 94 (SP), 77 (MG) and 70 (RJ). Espírito Santo has 30 state representatives.

In this sense, it is reasonable to assume that the assemblies of the Southeast make a more sophisticated and continuous use of digital tools, since they have a numerous and more digitalized audiences. Recent studies on the use of social media platforms such as YouTube (Santos \& Bernardes 2020) by subnational legislatures show that the assemblies of the Southeastern Brazil have a much 
higher number of posts than the other legislatures in the country, except for the House of Representatives and Senate.

This article is organized in seven parts: 1) introduction, 2) methodological considerations; 3 ) brief theoretical overview of studies about engagement, 4) comparative analysis of posts and comments in the four profiles, 5) theoretical discussion based on information collected in the interviews, 6) comments of users in the profiles of assemblies and 7) final considerations about the social media practices by the parliaments analyzed.

\section{Methodological Considerations}

The analysis of the institutional profiles that the legislative assemblies of Minas Gerais, Rio de Janeiro, São Paulo and Espírito Santo have on Facebook was initiated in August 2018 and the data recollection used two techniques: 1) in-depth interviews with the managers of digital communication of the houses and 2) comparative analysis of publications and comments made in official profiles on Facebook.

From August 2018 to January 2019 posts made on the four pages were collected through Netvizz application, discontinued by Facebook in September 2019. The data refer, therefore, mostly to the second half of 2018. During this period, the four assemblies published 890 posts that received 7516 comments. It is important to highlight that this number corresponds to the automated collection performed by the application, whose criteria are not evident and which may not correspond, therefore, to all publications made on profiles.

Simultaneously to the recollection of posts, in-depth interviews with the managers of the@assembleiademinas and@assembleiaRJ were conducted in person. The interviews with the managers of @assembleiaes and @ assembleiasp were conducted in October 2019, through digital channels. In total, 11 interviews were conducted (see Appendix 1), all of which were recorded with the managers' permission. The interviewees were chosen through indication of the employees, based on the researcher's initial contacts with the institutions. A script with the main topics of the approach was prepared (Appendix 2), but the interviews deepened the specific aspects observed in the profiles of each institution.

For each profile, each monthly period collected generates a specific graph, showing the most relevant data for the period. Thus, six monthly graphs were generated for each of the analyzed profiles. Below is an example of the configuration of one of these graphs (Figure 1), which brings the aggregate analysis performed by Netvizz of ALERJ's profile in August 2018.

The data highlights in which dates the publications made achieved the interaction of the public, either in the form of likes, shares, reactions or comments. The chart also shows the total number of publications, comments and reactions of citizens. In the tables generated in Excel by Netvizz you can also see the number of comments to each post, the content of these posts and also the comments themselves, as we will show in the data analysis item.

From the comparison of the contents of the publications with the content and the quantity of comments received it is possible to check which topics and which types of posts attract the most attention of the public. Interviews with managers allow a more in-depth reflection of these practices, providing data on the motivations and practical conditions of action of the teams. In this sense, the reflection of Leston-Bandeira (2007) on internal conditions of parliamentary organizations helps to understand the differences between the practices carried out by different institutions, even though the general objectives are similar. As 
Figure 1 - Aggregate netvizz analysis for August/18 - ALERJ on Facebook

Aggregate Analysis

17 posts covering the period from 2018-08-01 17:03:30 to 2018-08-31 15:45:00

118 comments (6.9411764705882 average)

452 reactions ( 26.588235294118 average)

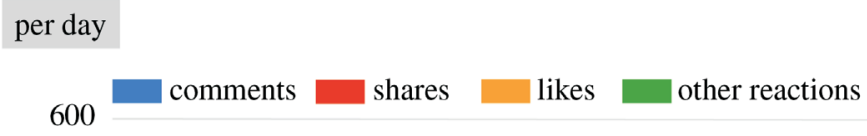

Source: Netvizz.

the author points out, the internal bureaucracy of legislative houses plays a fundamental role at various decision-making levels, especially in relation to the routines and daily practices performed in institutions (Leston-Bandeira 2007, p.664).

Let see how the literature of the area articulates the concepts used in this analysis. It is the theme of the next item.

\section{Parliaments, social media and engagement}

Among the consequences of the dissemination social networks use by political actors, some studies point to a new impetus to the "personalization of politics" (Enli \& Skogerb $\varnothing$ 2013). According to these authors, digital social networks are "semi-private, semi-public" spaces for self-representation, that is, places where the public and private roles of politicians and users mix and recombine (Enli \& Skogerbø 2013, p.759).

Obviously, this process is more visible in the personal profiles of politicians, such as parliamentarians or ministers. In Brazil, most studies on politics and social networks thematize the relationship of parliamentarians and/or candidates for public office with users of these platforms (Almeida 2017; Amaral 2016; Araújo, Travieso-Rodríguez \& Santos 2017; Barros, Bernardes \& Rodrigues 2015; Braga 2013; Braga \& Cruz 2012; Contreiras 2012; Miola et al., 2018; Tavares 2014; Tavares \& Quiroga 2015). Regarding the use of networks in elections, for example, Braga \& Carlomagno (2018) highlight that Facebook has become the preferred tool for candidates for majority positions in recent Brazilian elections, while websites and other social media such as Twitter have had a decrease in electoral strategies.

Regarding to Parliament as a collective institution, Leston-Bandeira \& Bender (2013) assess that social networking sites, or social media, have considerable potential to stimulate the ability of legislative institutions to promote citi- 
zen engagement. However, when analyzing the content of messages in the networks, the authors conclude that parliaments used the tools to report legislative activities, but not with the effective intention of seeking the engagement (2013, p.282). Obviously, the world and Brazilian scenario has changed since this publication, and so it is worth assessing whether legislative practices remain the same.

In this research, we use the concept of public engagement (Leston-Bandeira 2014) as a process with five aspects, from the point of view of citizens: 1) access to information, 2) development of understanding about parliament, 3) perception of the importance of the institution and identification of the relevance of its activities for life itself, 4) motivation to participate in the results of the legislative process, and 5) possibility of intervention and engagement in the discussion and legislative decision (Leston-Bandeira 2014).

Participation, in this sense, is only a stage of the process or flow, which can begin in any other phase and follow in different directions. It does not constitute, therefore, a "competing" stage with the representation performed by parliamentarians, since it is combined with the representative formal modalities. Thus, institutions can focus only on one, some or all stages of the public engagement process, without any of the institutional options necessarily constituting "failure" in the process. Obviously, from the citizens' point of view, it may be interesting to be able to effectively interfere in legislative decisions. This does not mean that the other stages of engagement - such as information or understanding - are not useful and even necessary for the expression of citizenship and for the relationship between society and parliaments.

Obviously, public engagement with legislative houses is not exclusively done through digital means. A guided tour of the parliament building, participation in a public hearing or in a demonstration in favor of a proposed amendment to the Constitution, for example, are forms of engagement far before the Internet. The point here, however, is to analyze how the different instances of the engagement process described by Leston-Bandeira (2014) can be carried out through Facebook, in the case of legislative assemblies.

Williamson (2013) is another author who signals the possibilities of harnessing the potential of social media by parliaments. According to him, the goals of legislatures on these platforms can be summarized in four points: 1) to provide new forms of communication and engagement with the public; 2) allow consultations to the legislation; 3) disseminate educational resources; and 4) promote transparency. Thus, digital resources are at the service of information, education, interaction and engagement. At the same time, such tools require a faster, more open and conversational approach of parliamentarians and civil servants, as they multiply communication channels and add complexity to engagement and interaction processes.

For Williamson, among the advantages of the use of social media by parliaments are: opening space for dialogue; user's approach to your audience; creating credibility and trust; encouraging greater transparency; opportunities to support minority parties or pressure groups; viral distribution; cost-benefit; better understanding of public opinion; real-time monitoring; reduction in the time to obtain information; inclusion as a central element of the communication, dissemination and engagement strategy. On the other hand, the entry into the environment of digital media also offers risks to the institution, such as: etiquette and protocols are different from other media; reputational risks if it is not authentic, honest and transparent; the need to be perceived as relevant by the audience, not by itself; carefully targeted content; potential to quickly get out of control; recruitment is difficult to predict and there is no guarantee of productive dialogue; is not a shortcut to communicative effectiveness. 
2 Accessed November 2019. During 2020, the author herself participated in the preparation of other articles on this theme, still in the publication phase.

\footnotetext{
${ }^{3}$ In this study, we opted for a theoretical approach based on the concept of Public Engagement. For more information on the concept of Public Communication applied to the communicative practices of Parliaments see Lemos, Barros \& Bernardes 2016.
}

\section{Institutional profiles in comparison}

The data shown by Netvizz makes possible to compare the number of posts of each profile. According to the data available on the respective Facebook pages, ALMG and ALERJ created the profiles in March 2011, while ALESP appeared in April of the same year. The ALES page, in turn, was created a year later in March 2012.

On November 8, 2019, it was noticeable that the number of likes received by the profiles and the number of followers had a significant increase in the period of 10 months, since the end of January 2019. At that time, @ assembleiademinas had 35,333 likes and 36,383 followers, with an increase of 4,844 followers, or $15.36 \%$ over the total it had in January. The profile @ assembleiaRJ had 42,911 likes and 43,635 followers, totaling over 6,008 followers, a 15.97\% increase in followers in the period. @ assembleiasp had the largest increase in the number of followers in the period, jumping from 41,083 in January to 49,017 in November, which meant $19.31 \%$. The profile had 47,658 likes on November 8 . The 
${ }^{4}$ Just as a curiosity, the profile of the House of Representatives on Facebook had 359,783 followers, while the official profile of the Senate had 3,294,528 followers on the same date. The Brazilian population reached 210.6 million people in November 2019, according to IBGE.
@ assembleiaes showed an increase of $13.13 \%$ in followers, which went from 13,383 to 15,140 in the period. On the same date, it had 14,536 likes.

It is noticed that there is a similar numerical reach among the assemblies of the three largest Brazilian states in terms of population: São Paulo (46 million); Minas Gerais (21.2 million) and Rio de Janeiro (17.2 million). However, Espírito Santo (4 million) has a high standard of access to the institutional profile of the state assemblies, if we consider its total population and the number of followers compared to the other states. In this sense, the smallest proportional reach is with the São Paulo assembly. In any case, in absolute terms, the scope of these institutional channels is very restricted proportionally to the population of these states. ${ }^{4}$

Figure 2 shows more clearly the quantitative comparison of posts between profiles in the analyzed period, based on the data available in Netvizz's charts. Despite the variation, the ALMG profile is the one that is most active, while ALESP and ALES exhibit great variation month by month. It is also interesting to note that between the first and second turn of the elections, in October, there were the largest number of posts in the entire period, also by the ALMG profile.

Figure 3 shows the number of comments received in each of the analyzed profiles. It is noticeable that some posts receive a total of interactions much more relevant than the average of the posts of each profile, although the number was relatively higher during the month of December 2018 for three of the assemblies analyzed. The case of ALESP is interesting in this sense, because it received the largest quantity of comments of the entire period in the month of August.

In turn, Figure 4 shows the data referring to the reactions received by each of the profiles. Again, one can see that only a few posts can reach a reasonably larger audience than the followers to the official page of the assemblies on Facebook. This is the case of the ALMG profile in October and December 2018, with interaction peaks four times higher than the best result of the other assemblies. The details of the data will be analyzed later.

Figure 2 - Posts by profile $\mathrm{X}$ month

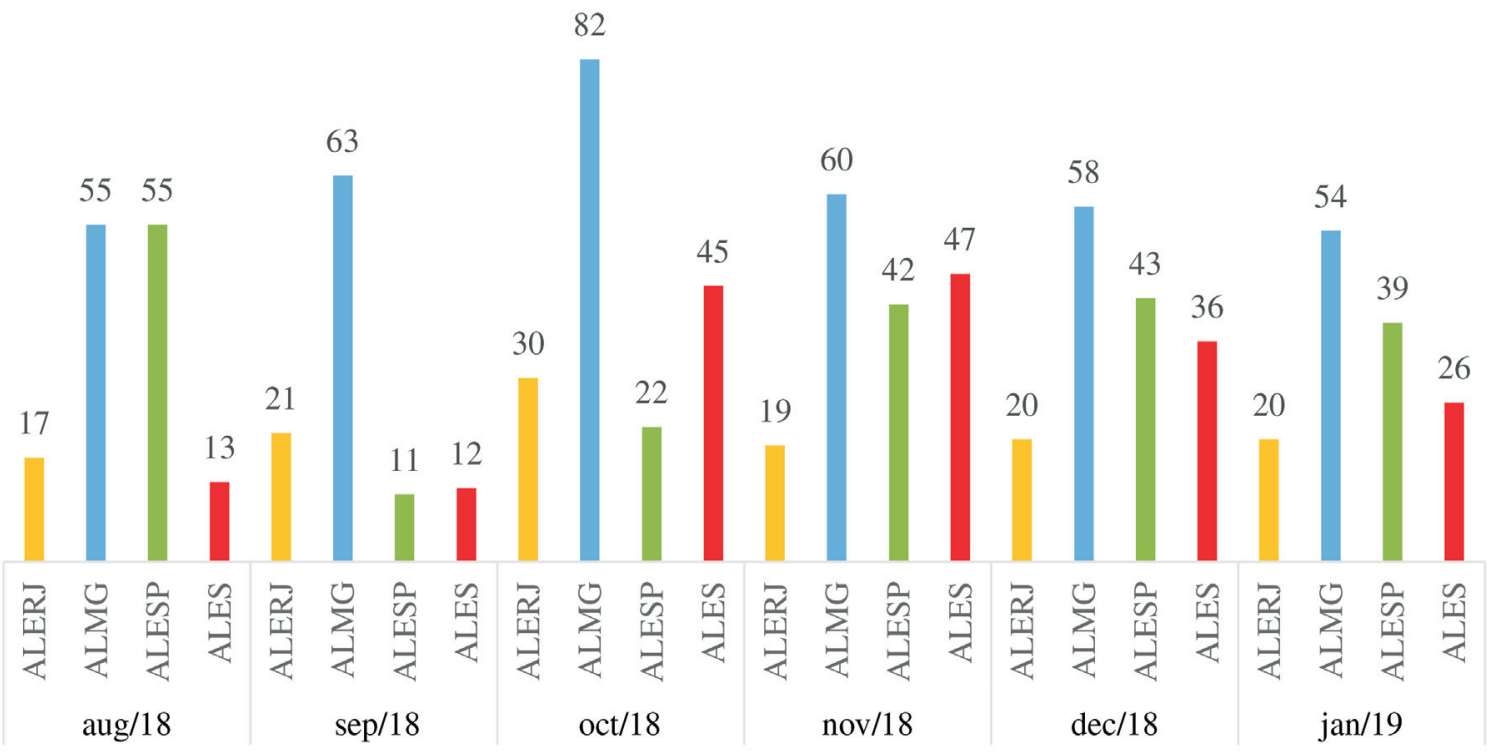

Source: Author's elaboration from Netvizz data. 
Figure 3 - Comments by profile X month

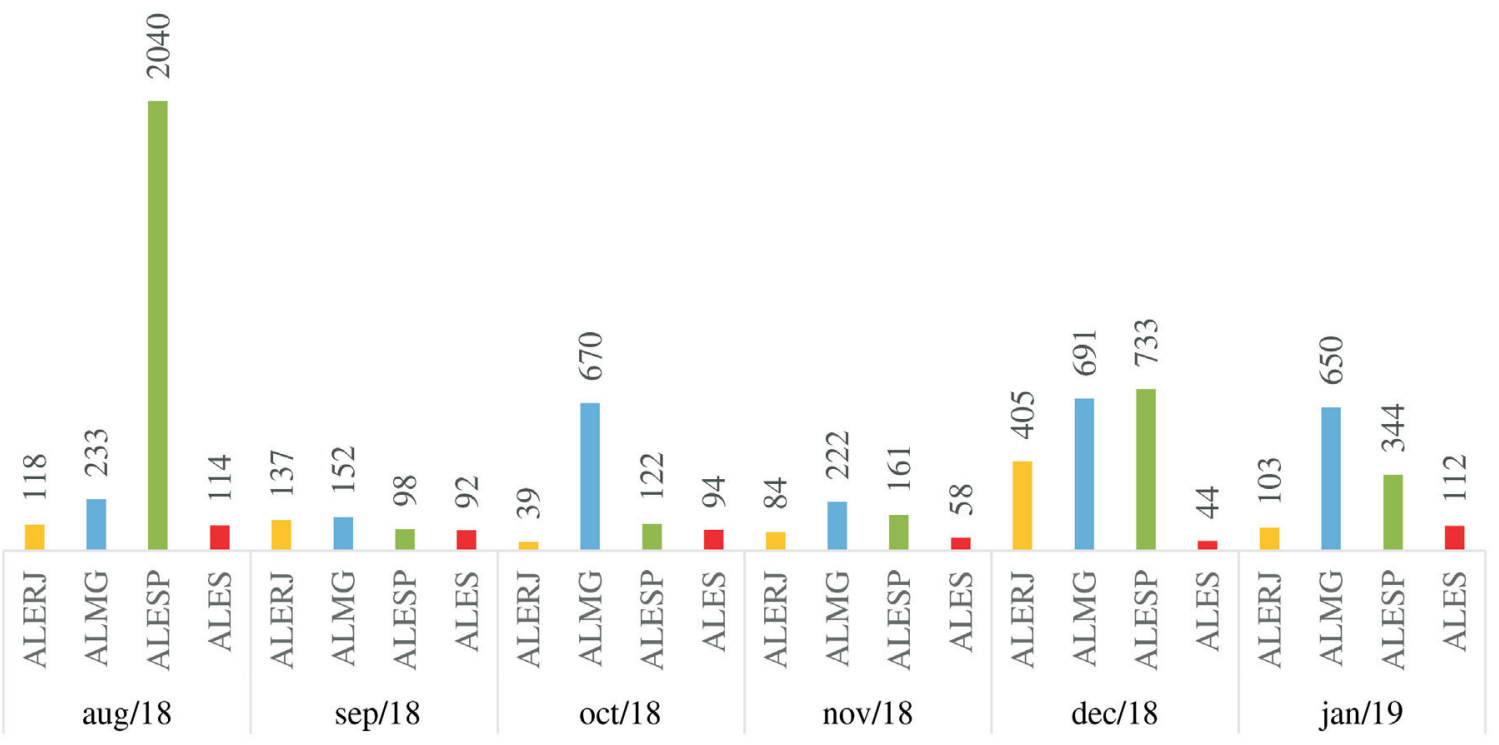

Source: Author's elaboration from Netvizz data.

Figure 4 - Reactions by profile X month

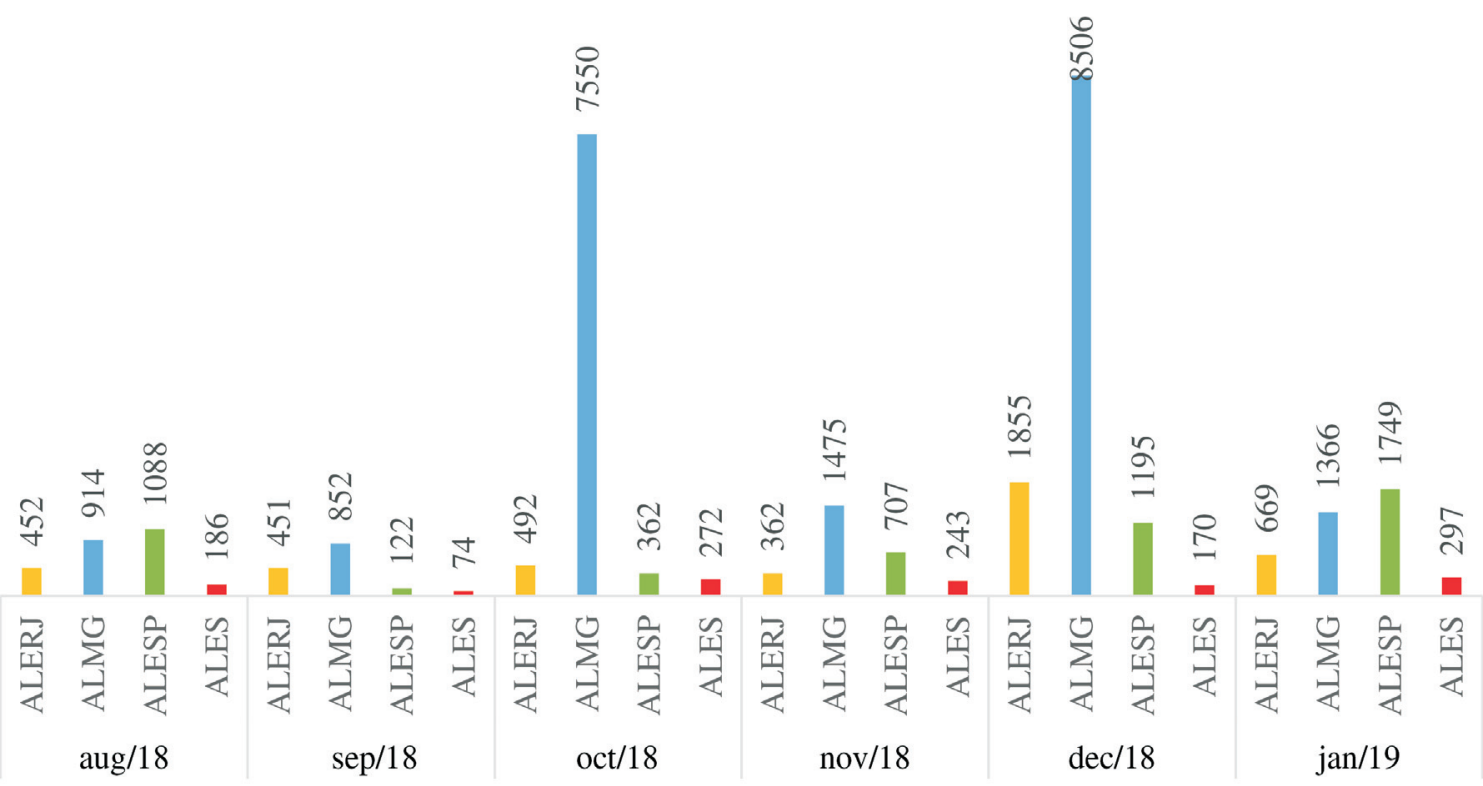

Source: Author's elaboration from Netvizz data.

From the data of Figure 5, below, one can notice that the @ assembleiademinas profile makes a more intense use of the tool, despite having fewer followers than the profiles of ALERJ and ALESP. In addition to the higher number of posts, it is the profile that achieves more interactions of citizens, especially through reactions to posts. It is also necessary to remember that the period in question had the limitations imposed by the electoral legislation between August and September - such as the impediment of publishing photos of parliamentarians in the institutional profile - which may have restricted the 
Figure 5 - Total interactions by profile

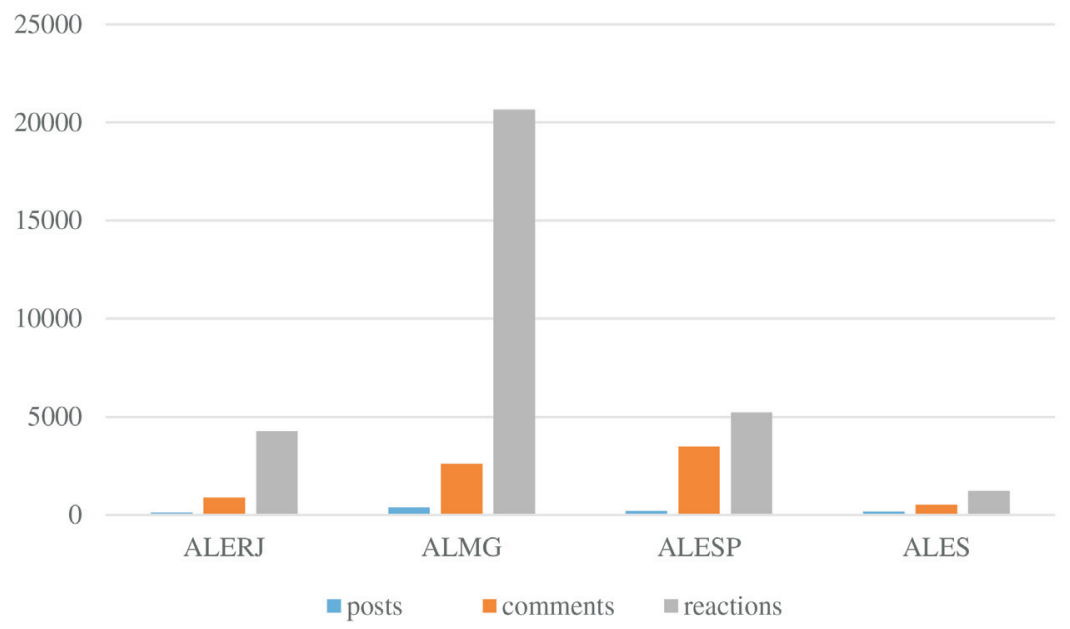

Source: Author's elaboration from Netvizz data.

use of the tool by all institutions and be an explanation for the low number of posts in the period.

In any case, it is verified that @assembleiademinas posted more and achieved an average of 55.54 reactions per post, much higher than the average obtained by the other three institutions, as shown in Figure 6. Regarding the comments, however, the @assembleiasp profile average is more than the double of ALMG's and ALERJ's and almost eight times higher than the @ assembleiaes. This means that ALESP has attracted the most polemic by connected users.

Next, the study provides a description of which posts generated more interactions and the possibilities of citizen engagement with legislative houses created from this content.

Figure 6 - Average reactions and comments per post

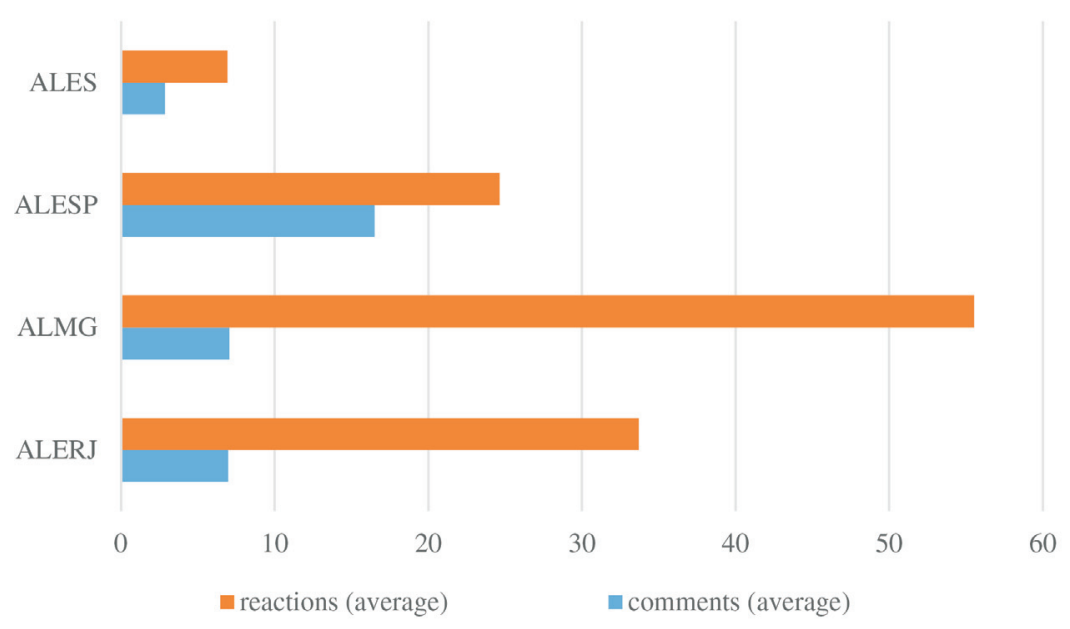

Source: Author's elaboration from Netvizz data. 


\section{Analysis of engagement spikes}

From the graphs above, it is also possible to identify the days when there were peaks of engagement in the profiles, with more reactions, comments and shares. The characteristic movement of all four profiles shows that there is a large standard deviation in the number of interactions per post, which makes the means not much informative. It is common for only one or two posts to concentrate more than half of users' contributions each month. Because of this, it is interesting to investigate what is the content of these posts that attract so much engagement. That is what is being done below.

Figure 1 shows that @assembleiaRJ's posts achieved much more engagement on 08/29/2018: 228 shares, 182 likes and 64 comments that day. Analyzing the posts, one can verify that Post 1, held at $13: 30$ on 29/08, reached nine comments. The post made the day before, at 22:05 on 28/08, received 45 comments.

Post 1: \#AgoraÉLei: The Executive Branch is authorized to conduct a technical feasibility study for the implementation of the Baixada Fluminense subway line and the extension of Line 4 connecting the Ocean Garden to the Alvorada Terminal in Barra da Tijuca.

Post 2: The project guarantees the free pass in intercity transport to students of the public network of all technical education modalities (integrated concomitantly and subsequently) and for students from public and private universities in the State of Rio. The proposal will go to Governor Pezão who has up to 15 working days to sanction or veto. The free pass in intercity transport was already guaranteed to elementary, high school and technical students of the state and federal municipal public networks.

The content of the posts refers to proposals under analysis by the Legislative House with a clear impact on the life of the state's population. As André Coelho, Deputy Director of Communication at ALERJ, points out, public utility issues always attract more attention from users on social networks.

${ }^{5}$ IBOPE is the name of the well-known Brazilian marketing and audiences research company, and it is commonly used as a synonym for public opinion surveys.
Topics of public utility always have good scope, viralize a lot the information about the laws in this sense. We play a lot here that IPVA always gives us Ibope ${ }^{5}$ For example, the law that allows to pay the overdue slips in any bank, or the end of the trailer of the vehicle due to debts with the DMV (A. Coelho, personal communication, 12 November 2018).

Tainah Vieira, coordinator of the Center for Marketing and Special Projects of ALERJ, informs that there is a priority for the posts called "Agora é Lei" (Now it is Law), which bring the decisions of parliamentarians on topics relevant to the public (T. Vieira, personal communication, 28 September 2018). Another item widely used brings information about the "Consumer Bus", an initiative of the Consumer Protection Commission that takes a bus with civil servants to different municipalities to clarify about the rights and collect complaints. She points out that "it's not all that comes in", because there are technical limitations. "We usually do a maximum of three posts a day on Facebook, we don't post too much for content not to disappear into people's timelines," she says.

Regarding the profile @ assembleiaRJ, there was also a peak of user activity on December 11, 2018. On this date, several posts reported on legislation approved by state representatives. Post 1 , which reported on the governor's approval of the inter-municipal free bus pass for technical education students and public universities, received 214 comments, several of them marking other users to access the information. It is interesting to note that the subject had already been widely commented in August, when the proposal had been approved in the Legislative House. 
Post 1: \#AgoraÉLei Intermunicipal free pass is guaranteed for students from the public technical education network and public and private universities of the State of Rio. Check out the 47 new laws that were enacted today by ALERJ.

The post on annual vehicular licensing (Post 2), in turn, was the subject of 47 comments. It is interesting to highlight that most posts get very few comments, while a few posts receive most of the contributions from users.

Post 2: \#AgoraÉLei The annual vehicular licensing can be carried out through the DMV-RJ website. The owner must make the self-declaration that the car is in perfect working condition with the vehicle and environmental safety.

In terms of user engagement with the @ assembleiaRJ profile, December 11, 2018 brought 660 likes, 854 reactions, 220 comments and 3396 shares. The figures indicate that most users considered the information produced by the Legislative House relevant enough to be disseminated in their networks.

Peak days of user interaction also occur in the other three profiles analyzed, as mentioned. In the case of Minas Gerais, two publications achieved high levels of user engagement in the week leading up to the first round of elections. On $01 / 10 / 2018$, a post made at $22: 16$ and calling voters to the polls reached 190 comments. In total, there were 3854 likes, 4280 reactions, 1452 shares, which generated the engagement of 5922 Facebook users.

If you don't let them choose the taste of your ice cream, why would you let them choose your candidate? Don't let them decide for you, your vote changes everything. Vote for me! Go to: almg.gov.br/seuvotomudatudo \#VemPraUrna \#VocêFazPolítica \#Eleições2018

Two days later, on 03/10/2018, at 18:00, a new post with the same content reached 138 comments, 1806 likes, 1961 reactions and 698 shares, engaging 2797 users.

Can you imagine going to a restaurant and the attendant choosing your food? Do you give up your choice? That's what happens when you decide not to vote: someone chooses for you. Your vote changes everything! Vote for me. \#Eleições2018 \#VocêFazPolítica \#VemPraUrna

The ALMG team points out that conducting awareness campaigns on issues related to politics and Parliament, in addition to issues of public utility, is one of the priorities of the use of social media. The two posts above exemplify the type of content that receives attention, with an emphasis on videos and educational products.

Obviously, not all engagement is positive, in terms of the public image desired by the institution. This is the case, for example, of the post made at 18:24 of 22/12/2018, which received 6904 likes, but 7384 diverse reactions, 1088 shares and provoked the engagement of 9016 Facebook users. With a short text, the post featured a video summarizing the work of state legislators that year.

Work, responsibility, commitment and dialogue to meet the challenges. Want to see the work of the Legislative Assembly? Go to: https://bit.ly/2RjZIHb

If seen only on numerical terms, the success of engagement can make satisfied the civil servants that manage the profile @ assembleiademinas. However, a more in-depth examination of the content of the 544 comments shows that the public image of parliament and the level of trust of citizens in the institution may not only be influenced by a rational assessment of parliament's performance, but also by the image of the political system in general and by the forms of symbolic identification with the institution (Leston-Bandeira 2012, p.522). Corruption scandals at different levels of government directly affect the image of political institutions and the legislature, due to its own characteristics - extreme visibility, public control, lack of unique identity, vocation to conflict, etc. 
- seems destined to "not be loved" (Leston-Bandeira 2014). This is what the following comments show:

Work, responsibility, commitment?!!! Are you sure it's really ALMG? The same one that "ruled" next to the pilantrel???? There are so many doubts.

Their pay is up to time and their privileges are up to it! we on this side, that we put them there we have not the slightest respect!

They did everything so well that it's the way it is, total chaos!!! How wonderful!!!

Applause for you who buried the State of Minas Gerais ... You're not ashamed to release this video??? It doesn't hurt in your conscience to tell so much ???

Where were you when the Supreme Court blocked the money from Minas Gerais? What did you do to enlighten the public about the issue before the elections? Didn't you feel sorry for the suffering of functionalism? Shame!!!

Seriously! The state and municipal public service without receiving (diversion of FUNDEB) and this lying propaganda, paid with our money diverted, stolen, of this GOVERNMENT

DAMN PT! Who are you kidding? Only their alienated militants who voted and support these RATS in government! ??????????????

What money will you spend on this commercial..... Stop it.... Just work.

Congressman's job, that's what Steve Wonder would say: I only believe seeing.

Deputies were elected to work end point

I'm going to pretend I believe rats.

Then, at ALMG, the money rolls loose!!!!! Extort the people with high salaries, advisors and stewardships and pay nice and necessary! Ffa!!!!!

At ALESP, the same situation occurs in a post on August 21, which called internet users to follow the session live with a very succinct text.

Watch Tuesday's session live in the Legislative Assembly ;) Join engage in discussions give your opinion on the topics covered! \#ALESPAoVivo

It is interesting to notice that the post was the second to receive more comments that month, according to the record shown in Figure 7.

In any case, the content of the more than 250 comments shows that increased engagement does not mean that the goals of institutional communication related to expanding confidence or improving Parliament's image are being achieved automatically. As shown in the following statements by internet users:

On the ship DEATH AND PAIN, SHAMELESS PROFIT, ENVIRONMENTAL CRIME, ANIMAL SUFFERING!!!! \#APROVAPL31

Election year will now come that the people are tired of taking in the bath Maria

Intolerant practice Cauê Macris???? Intolerant is this his behavior as president of ALESP!!!!!!

You're supporting ranchers to exterminate the planet!!!! Do you have any idea of the destruction caused in the forest so that pastures can be created????????

Use SO MUCH money in a LEGEND, if it were to use in social assistance, animal cause

What do you mean change? Do you analyze projects according to the improvement and logic of this to the state or what it pleases you?

Just election campaigns. No work they were hired for.

I want to make 25,000 going to the full-back once a month and not voting at all.. what a good life of deputy in brazil $\mathrm{f} * * *$ 
Figure 7 - Aggregate netvizz analysis for August/18 - ALESP on Facebook

\section{Aggregate Analysis}

55 posts covering the period from 2018-08-01 16:00:02 to 2018-08-30 23:20:32

2040 comments (37.090909090909 average)

1088 reactions ( 19.781818181818 average)

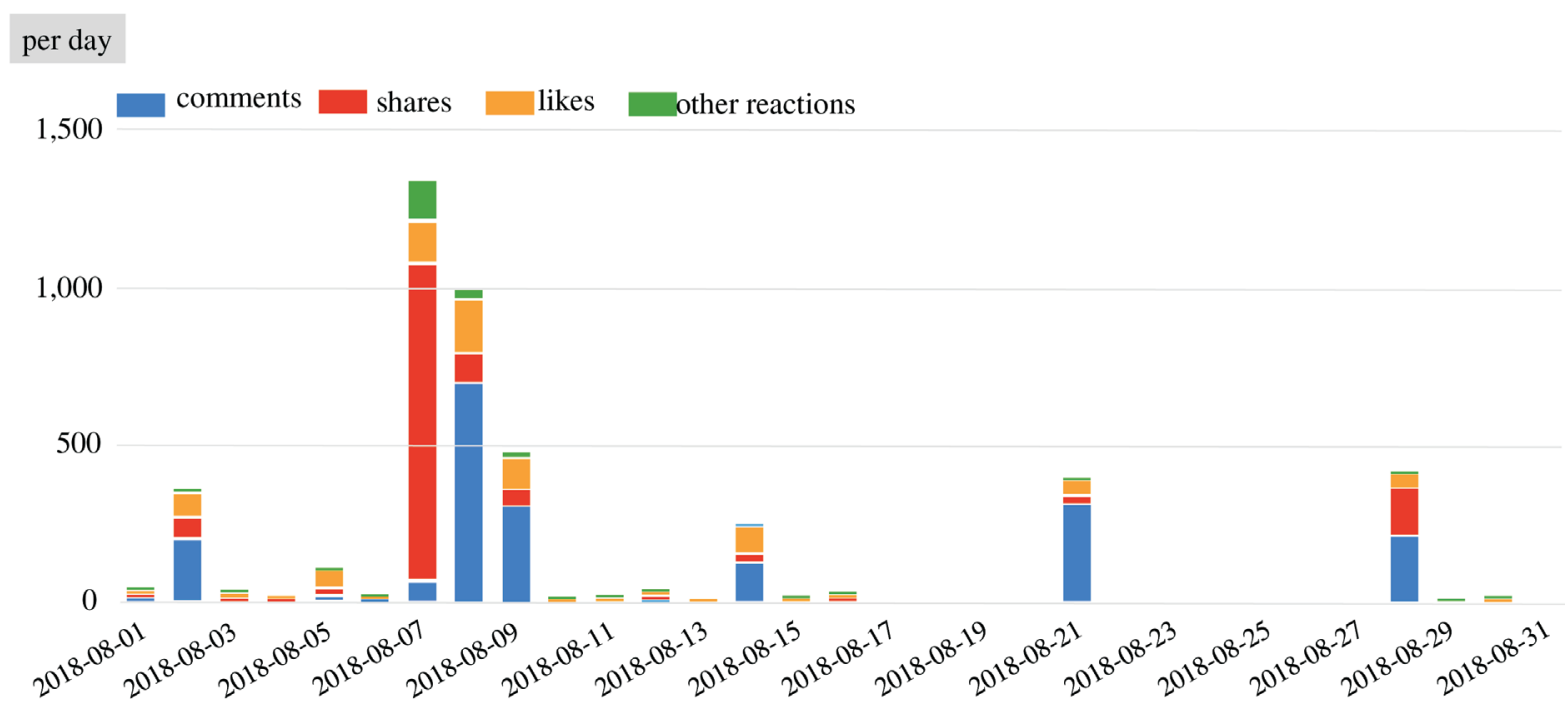

Source: Netvizz.

The biggest problem of this fully there is the school of leaders, voting the dark disrupting the whole process of the agendas!

Figure 7 also reveals that the greatest quantity of comments and reactions was made by internet users between 7 and 8 August, also in posts about live discussions. On the dates, the bill 31/2018 was under discussion, which prohibits the shipment of live animals in maritime and/or river transport, for the purpose of slaughter for consumption. There were, in total, 480 reactions, 769 comments and 1104 shares of the nine posts made in the two days. The number of likes, however, stood at 317 . Among the comments made by users appear:

\#p131 \#pautapl31 \#aprovap131 \#alesp \#eleições2018 \#portovergonha \#estamosjuntxs \#wearealltogether \#banliveexport \#saopaulo \#cauemacris \#nacaoveganabrasil \#exportandovidas \#crueldade \#brasil \#animais"

The negative karma with nature is bigger as time goes and from the law of cause-effect you will not escape!!!!

Stick to PL 31. ALESP, fulfill the role, through its president, Cauê Macris, to meet the people's call for this project to be guided and voted on. It is the people who cry! \#pautapl31 \#aprovap131

That's why for me is enough of the PSDB in power, ended up with São Paulo and now wants to end Brazil.

Perfect, Feliciano Filho! Vote project out of the usual days, to approve just what they want!

The assembly is asleep, accommodated, full of people who do not want to work.

We are connected in all the meetings that take place there! We're not stopping until we're voted on!

Enter day ..... comes out day...... enters day...... comes out day....... And you don't vote for anything!!!!!! Sad reality of this Assembly paid for by taxpayers!!!!!!!

See why is it taking so long? Wow, only now have you guys heard about this? Are you not paying attention to the floor?? 
Lack of respect and whistle think wrong, but activist can manifest, we do not live in a dictatorship.

The pattern of posts in the profile of ALESP during the analyzed period invites citizens to the live transmission of debates and votes. As explains Manuela Sá, Editor-in-Chief of the Communication Department of ALESP and responsible for managing the profile since May 2019, the option made by the small team is to offer a summary of what was approved or discussed in committees and plenary.

We usually post what was done on the day. For example, five projects were approved yesterday, today there will be summaries of committee meetings. We publish what goes to the Official Gazette and the website, but [still] there is no specific planning for social media, about what people want to see in them (M. Sá, personal communication, 24 October 2019).

According to her, the management of ALESP's social media is in a transition period, because there was the loss of the hired professional who performed the task and, therefore, the team is trying to train another person who will be exclusively dedicated to the management of social media, which had not yet happened until October 2019, when we conducted the interview.

In the period analyzed, only in another situation the number of comments was significant: in a post made on December 18 on the graduation of new deputies elected in 2018. On that date, 425 internet users commented on the post, which had the following content:

Watch live the graduation of state and federal representatives, governor and vice of São Paulo elected in 2018 :) The diploma is the act by which the Electoral Court attests that the candidate was effectively elected by the people and is therefore able to take office.

Jail for all the corrupt politicians

Also in this case, it is noticed that the reactions of users of the institutional profile do not seem to be in accordance with the institutional goals of the teams that manage these tools.

Jail for all the corrupts

Frota kick out this communist trash! Lol

EVERYBODY MAKES THE “L DE LADRAO” (T FOR THIEF) ????????

Enough from these garbage ele não (He not) lol

FABIO BRANCO YOUR MENTAL SICK

ALWAYS THESE FOOL ACTIVISTS

The left is a shame

Congrats Doria!

Lula is in jail, bastard lol

Go Alexandre Frota, take a right punch on these rioters from PSOL

NEXT YEAR YOU WILL CELEBRATE THE ISLAMIC STATE? THIS YEAR WAS MST TURN

I wonder if anybody from the left were reelected... corrupts

God save us from these people elected from PT

It has to be the shit of PSOL ?

In turn, if the case of the Assembly of Espírito Santo is significantly different regarding the quantitative aspect of access from the examples of São Paulo, Rio de Janeiro and Minas Gerais, it is noted that the same pattern of content of 
the posts and comments of internet users to other institutions. As Lucas Albani, responsible for design and social media management of ALES, explains, the posts bring more news content, since the reduced team cannot afford more specialized work. Even so, each social media has a specific posting strategy:

Facebook brings a lot of live sessions, which is something that has a lot of demand. The work that takes place in the House, the articles we give on the site, the summaries of the sessions, visits, approvals of matters, debates that are in progress (L. Albani, personal communication, 25 September 2019).

A good example is the post of August 1, 2018, which demonstrates the common pattern of publicity of legislative decisions in the Assembly of Espírito Santo and received 31 contributions, a number well above the average of 2.87 comments per post.

Wednesday's regular session marks the return of legislative work after two weeks of parliamentary recess. The voting agenda is headed by Bill (PL) 262/2018 establishing the Water Spring Protection Program. Nunes's proposal (PT) is urgently handled and will receive an oral opinion from the Justice, Environment and Finance committees. \#assembleiaes \#sessaoordinaria \#aovivo \#nascentes \#projetodelei

As in the profiles of Minas Gerais, São Paulo or Rio de Janeiro, we realize that the open interaction with the institutional profile of the Legislature in social media serves, mainly, as a space for the discharge of the generalized complaints of the population against the world of politics and parliamentarians in particular.

14 people watching this session... what a shame

B

Getting the job this way is a shame

Let's change this house completely

And what are you representatives of the people doing? eating flies for sure.

What a shame ... fail to appreciate a matter for lack of quorum

These current state legislators are doing absolutely nothing missing two months we're going to take out these current state legislators are not doing absolutely anything out all out let's please folks don't vote anymore these current state legislators i'm saying all

However, one can see not only criticism on social media. In some specific cases, when certain interests are met by Parliament, there may be room for praise and for more respectful interaction with the representatives of the population. A January 2019 post on the ALES profile shows this perspective.

Follow Wednesday's legislative work live. It is urgently pending the draft Complementary Law No. 03/2019 from the Executive Branch that grants amnesty of penalties and administrative procedures imposed on the state military due to the crisis in public security that occurred in February 2017. \#assembleiaes \#sessaoextraordinaria \#aovivo

This post seems to have attracted the attention of people directly affected by the issue, which caused a positive repercussion that was not often seen in institutional profiles during the analyzed period. One detail, however, needs to be highlighted: the confusion between executive and legislative branches, so commonly reported by authors dealing with parliamentary regimes, seems to take place also in presidential countries such as Brazil. Both in the case of criticism and name-calling, as in the case of praise, the roles of the different powers seem to blend into the popular imagination, to the dismay of the communicators of the Legislature, who almost always succumbs to the personalism of the executive figures. 
Congratulations to Governor Renato Casagrande and the deputies for the amnesty project to the Military Police, now the institution will be re-erected with the return of the dignity of the Military Police, return of the BME - Battalion of Special Missions and ROTAM - Motorized Tactical Round, finally our Military Police that we provide services to 183 years back.

Amnestyyyyy

Congratulations PMES, I was there for you!!!

I am very pleased with what is happening, I struggled to help colleagues who were excluded by an administration, in which the gov was quoted baianinho, in the Car Wash operation, many colleagues are in need, did not imagine that the governor did it so quickly, Mr. Governor my respect.

by the families of the military who took their lives also because of this little puff

Don't forget the mothers, wives, sons and daughters.

Amnesty now! Renato Casagrande is undoing evil, the dismay of the previous government! Congratulations Governor Renato Casagrande! God bless you!!!

The days and nights ahead of the QCG were not in vain.

In general terms, therefore, the engagement in the institutional profiles of the Legislative Houses tends to happen only when citizens perceive the relevance and direct influence in their lives of information and content posted on social media. Thus, the pattern found in the data reveals that there is more positive interaction with posts that are more specific and deal with issues of public utility, especially legislation whose practical effect on everyday life is quite visible. On the other hand, posts aimed at transparency and the balance of activities carried out in legislative houses, many of them with an institutional communication content, do not always find a good reception among citizens who interact with profiles.

The dynamics of interactions with profiles demonstrates that the stages of information, understanding and identification (Leston-Bandeira 2014) with the institution can be carried out daily in Facebook profiles, although we may question whether participation and influence on decisions would be possible in this context of social media platforms. Whether when they feel represented or when they feel harmed by legislative decisions, citizens' engagement is conditional on the practical issues being decided in parliament. If this is a cause or a consequence of the informative choices that legislative communication teams make, we cannot confirm in the limits of this work. It is interesting, however, to highlight the existence of this relationship between the two aspects of the activity: content of posts $\mathrm{X}$ user comments.

\section{Social Media for what?}

The comments of users in the profiles of assemblies show that, as a sounding board for public opinion, the institutional pages of the Legislative Power on social media can also be a space for outbursts for users. In addition to complaints and name-calling, disbelief and cynicism with representatives and the terms of the political game are vehemently expressed. Something that does not go unnoticed by the managers of the profiles, as Daniel Tiriba, journalist and designer in charge of the production of content for social media at ALERJ.

Today it is more difficult to work the relationship with users because of anti-politics or personal problems, especially among state employees. (...) And then there were the demonstrations of 2013, and the subsequent demonstrations of public servants. Resistance to politics has always been, but now the discussions are very heated. Before there were some compliments, today they are very rare. In the social media is reproduced the movement that is seen in the streets. The net has be- 
come a battlefield, people use it to attack each other, and you end up in the crossfire sometimes. Then we need to think about what it's worth to be amplified by a comment or response (D. Tiriba, personal communication, 28 September 2018).

Despite the awareness of the mishaps, the managers of these interaction vehicles continue to bet on the function of these spaces as entrance doors to the Legislative House, from the dissemination of relevant information about the production of laws, functioning as a service to present to the population issues in which it is interested and that directly affect their life. As Leston-Bandeira (2016) points out, showing the relevance of parliament to people's lives and making the public value this role are the two main justifications for the implementation of engagement tools in the Legislative Houses. "It's a form of direct contact," says Celia Abend, General Director of Social Communication at ALERJ.

Generally, we cover the proposals under discussion in ALERJ on official YouTube profile and make lives with Members on Facebook on topics that are in evidence, that have repercussions in society and for which parliamentarians also have interest. (...) When it comes to society, we manage to capture them for discussion in a more positive way (C. Abend, personal communication, 3 September 2018).

One question that arises in any analysis of the use of digital tools by political institutions is how to connect granular information from web 2.0 environments with real political decisions (Chadwick 2009, p.40). In other words, how to make the digital action of citizens result in political decisions or influence the action of political actors. The internal organization of houses and the infrastructure available to institutional actors also deserve attention since the resources and professionalization of institutions are highlighted as important in the structuring of engagement services and in the use of digital tools by parliaments (Leston-Bandeira \& Bender 2013).

The digital resources of social media are at the service of information, education, interaction and engagement (Williamson 2013, p.10). At the same time, such tools require a faster, more open and conversational approach of parliamentarians and civil servants, as they multiply communication channels and add complexity to communication, engagement and interaction processes. It is perceived, for example, that the need for response in interactions via social media is more intense than in other digital channels, also for political actors. In an experiment that verified the level of responsiveness of Brazilian parliamentarians, Carlomagno, Braga \& Sampaio (2018) showed that the response is much higher in Facebook inbox interactions than in communications using email. Even so, the study reaffirms the low rate of response to citizens by Brazilian federal deputies.

This complexity and need for dialogue present in social medias mean, among other factors, that all parliamentarians become producers of specific content, to be shared on their own channels with their voters and potential supporters, from whom they receive feedback. It is common, for example, that members disclose in their profiles the material produced by the institutional communication teams in charge of social media. As André Coelho reports, until July 2018 (before the election period) it was common to hold lives on the official Page of ALERJ on Facebook with parliamentarians. On these occasions, the themes usually brought the proposals under analysis in the House.

They loved the format, posted it on their social media as well. The topics of the interviews varied widely. Sometimes the congressman asked to do it when he had some project of interest or authorship of him. (...) We realized that it was more interesting to bring to the interview a deputy related to some topic that was 
already on the public agenda, than to try to guide something new in their interest (A. Coelho, personal communication, 12 November 2018).

This manager also informs that, since 2015, there has been a substantial change in the way the institution started to use the social media. If before the scope was small and the use focused on Members - usually the news about a project was accompanied by the photo of the author or rapporteur of the proposal - from there the focus became the theme of the proposition. According to Coelho, this brought "more connection with the population".

Some members complained about the changes, wanted their photos on the Facebook page, liked it when it was more personalized. Not everyone understands the proposal very well, but we always explain it to them. Some agree with us when we explain. For what is the relevance to the citizen of the photo of the parliamentarian? It does not generate user engagement (A. Coelho, personal communication, 12 November 2018).

For Lucas Albani (personal communication, 25 September 2019), of ALES, it is also important to differentiate the institutional use of profiles from the political use that parliamentarians make of social media. "We have 30 Members, so we don't focus on any of them. We are in mind that if we give them a lot of space, we become advisors to parliamentarians," he said.

Another issue related to the complexity of interactions added by social media is the attention to the demands of the population sent through these channels, which directly reflects on participation and its influence on political decisions, steps not always achieved in the engagement process. At ALERJ, since 2015 there has been the hiring of interns for the team, to give more attention to questions and comments of citizens. Tainah Vieira explains that there are standard answers on some more common matters: internships, free pass, guided tour, gratuity of the elderly in public transport (there have been recent changes in legislation), which are usually sent in the inbox by Facebook or Twitter. Second, responses are sent privately to the user because there is a difference in how they react to this strategy.

We answer by inbox because we notice the difference: it seems that they know that there is someone, a person answering there, personalize the relationship more and create empathy. In open comments this does not happen (T. Vieira, personal communication, 28 September 2018).

The entry into social media presupposes, therefore, that participants are all seen as active in the communicative process, something that is not the keynote when it comes to institutional or massive communication. But what does it mean to be an active participant? According to Williamson (2013), he is the one who can perform four basic tasks: listening, answering, asking and sharing. Thus, the profiles of political actors on social media need to perform these four activities, in addition to allowing other users to also perform them.

The Institutional Relations Manager of ALMG, Daniela Menezes, agrees with the importance of the engagement of citizens with the institution through digital tools. According to her, it is necessary to develop a "relational perspective", more than just informational in these vehicles, to regain the confidence of the population in the Legislative Houses.

They must have the EXPERIENCE OF POWER in the events of ALMG, participate in these events. (...) Only the distribution of information, however good it may be, will not generate this experimentation and trigger certain fields of knowledge and interest essential to citizenship. We know that proximity generates a decrease in distrust and predisposition to participate, to be involved in the political process (D.S.M. Menezes, personal communication, 14 November 2018). 
For the ALMG Digital Media Management team, institutional Facebook serves, as a priority, for dissemination of educational campaigns aimed at providing services to citizens. Created in 2013, the profile has most followers concentrated in the metropolitan region of Belo Horizonte and in two of the largest cities in Minas Gerais: Uberlândia and Juiz de Fora. From a broader monthly planning and weekly agenda meetings, five journalists, five designers and three interns discuss with manager Ana Carolina Utsch Terra what the actions will be developed and what content will be produced for the different media. There are two main criteria for the choice: 1) the issues related to editorials in the social media and 2) the ALMG agenda.

"Bringing service to citizens is a strong role that we have," Terra explains (personal communication, 16 October 2018). In this sense, the information provided is essential for the other levels of engagement to be achieved, especially the understanding and identification of the relevance of parliament. Examples are the posts about Elections in the series "ALMG explains", with posts about different aspects of elections, functions of elective offices, etc. During the election campaign were also made lives in partnership with TV ALMG with analysts and political experts, especially participants of the program Political World. In addition to producing informative and educational content, the team is also responsible for developing the applications used in the Mobile version of the tools.

A perspective with which also agrees Coelho, from ALERJ.

I think social media help a lot to clarify people's doubts about the Legislative Branch, because we see that citizens still confuse a lot of the attributions of ALERJ with the federal and municipal legislatures. They don't know exactly what each of them does. We invest a lot in educational issues, because we see the ignorance of people in this area, about our functioning. I think this is something very interesting (A. Coelho, personal communication, 12 November 2018).

In turn, the ALESP team focuses its practices on issues that give transparency to parliamentary decisions. More than providing a specific service, the idea is to disseminate the basic information about the legislative process and translate it to promote citizens' understanding of parliament, stages of the flow of engagement emphasized by them.

The main objective of social media is to achieve transparency for the legislative process. It's very technical information, difficult to understand, even I, when came in here, have said I needed to be literate again. So, the intention is to chew this content, make it simpler and more direct so that the average citizen can understand it, can understand what is being done within ALESP. We try to translate this information more simply and quickly for the citizen (M. Sá, personal communication, 24 October 2019).

If the main objectives of the action on social media by the Legislative Houses are, as André Coelho informs, to increase transparency and information about the legislative process, Williamson's theoretical considerations (2013) about the claim of a more active role to the citizen make sense.

To this day we have a practice focused on let politicians talk, we act as a one-way street. But people want to participate, they want to be heard. I think we need to take advantage of this very diffuse interest and call them to better understand Parliament, see how things happen in here, because there is a lot of misinformation about the inner workings of the Legislative House. However, there is also a growing interest of people in politics (A. Coelho, personal communication, 12 November 2018).

Similarly, the Director of Planning and Coordination and Coordinator of the ALMG Portal Steering Committee, Alaôr Messias Marques Júnior, emphasizes that communication and technology are basic to seek public recognition and 
bring the notion about the role and result of the work of the Legislative House to the citizens (personal communication, 16 October 2018). Or, to promote public engagement from the three levels of access that need to be sought: Information, which is the most basic; Communication, to allow more contact, more interaction; Education, to create a new perception of Parliament.

Of course, there are different reasons why assembly profiles on Facebook favor informative content, not more fruitful dialogue strategies with citizens. In addition to the platform's own use and design logic, which are not the focus of this article, the content production strategies of legislative houses are carried out by teams, in general, small.

In this sense, of the four assemblies analyzed in this study, ALMG is the only one that has a large team and, therefore, shows a more professionalized management of the policy of use of digital tools. Five webdesigners, five journalists who produce content, a manager, two advertising interns and a journalism intern take the time to produce content exclusive to the social media and the Portal. There are some specific advances in the educational direction of the content, although monitoring and direct contact with users are not considered ideal by the team, precisely due to the lack of exclusive dedication to the social media.

Fabíola Farage, General Manager of Press and Dissemination and manager of the ALMG Digital Presence Project, points out that the production of specific content for social media is difficult without a team dedicated exclusively to this full-time (personal communication, 15 August 2018), especially due to the answers to comments and questions, an argument also highlighted by Griffith \& Leston-Bandeira (2012). At ALERJ, Tainah Vieira (personal communication, 28 September 2018) follows the same line of reasoning and advocates the production of exclusive content and greater attention to comments. "I think profiles on social media work like a Customer, so we should always respond to comments," he says.

While ALERJ had two professionals and two interns for social media management, ALESP and ALES had only one professional responsible for the activity, as well as interns. In the case of São Paulo, there is no exclusivity in the activities of these professionals, that is, they are also in charge of other tasks, besides the management of content and relationships in social media. Lack of monitoring of public contributions and lack of direction in direct relationships are some of the specific problems that arise due to the few investments in the activity, from an institutional point of view. As Manuela Sá points out, "the problem is that we don't have the monitoring of this material, we don't do anything with the comments that come in" (M. Sá, personal communication, 24 October 2019).

The lack of material and human resources for the management and efficient planning of digital communication prevents the tools from being used to their full potential, a point considered fundamental by Leston-Bandeira $(2007 ; 2014)$ in the process of digitizing parliaments and promoting engagement. This means that social media are used only on an informative, unidirectional nature, without attention to their interactive and communicative functions with a whole, especially as a resonance box and as a form of direct contact with the population. Feedback opportunities that are not taken advantage of, as managers are well aware of.

Even with the practical obstacles pointed out by managers, the discourse mobilized by them goes in the same direction as the theorists point out: the need to promote processes of citizen engagement with the legislative institution, 
through social media. Basically, to ensure that the representative role of parliaments is fulfilled and trust in the institution is restored.

\section{Final Considerations}

In this study, the combination of two different techniques for collecting and analyzing empirical data - comparative analysis of posts and comments on Facebook and in-depth interviews with the managers of these profiles - allowed a deeper understanding of the patterns of use of social media platforms by Brazilian parliaments. More than just evaluating what was published by the institutions, we sought to understand the production logics involved in the activity, as well as the response of citizens to this practice of digital communication.

Thus, comparative data reveal that the @assembleiademinas profile made more intense use of Facebook in the period analyzed, despite having fewer followers than the profiles of ALERJ and ALESP. In addition to posting more, ALMG's profile achieved more interactions with citizens, especially through reactions to some posts made in October and December 2018. Among the four assemblies analyzed, ALES' profile had the lowest quantitative reach, in number of users who interact, both in relation to reactions and comments. ALMG has the profile that received the most reactions per post, while ALESP received more comments per post in the period.

The data presented also reveal that an informative pattern on legislative activities has been maintained in these channels. The reasons for this are varied, but it seems central to it the complaint of managers about the lack of human and material resources for the fulfillment of activities of a more educational and engaging nature in the social media, something that Leston-Bandeira and Bender (2013) also perceived in the European parliaments.

Some specific attempts to intensify the other elements of the flow of engagement in the direction of participation and intervention on legislative activity are made with the dissemination, for example, of the agenda or the result of the votes in the different stages of the legislative process. The intensity of the response to the citizens who interact with the profiles, however, is considered insufficient by the platform management teams themselves.

As pointed out earlier, the interest of citizens who use these spaces is directed to practical issues and immediate decisions of the Legislature, especially the legislative production that influences the daily lives of citizens, as mentioned in the analysis. In cases where results of the legislative process are visible, exemplified by the approval of laws that directly interfere in social, economic or political fields, users more easily perceive the relevance of discussion and legislative decision about their lives. Only on these occasions the cycle of engagement proposed by Leston-Bandeira (2014) seems to be carried out with more interactions of citizens in the profiles, especially in relation to information, understanding and identification of the relevance of parliament.

However, as shown by the data - both the comparative analysis of the comments and the interviews with managers -, the interaction does not always have a positive bias, in terms of maintaining the image and producing dialogue with citizens. At times, the polarization of opinions in social media and the distrust of citizens regarding political institutions intensely affects the result of interactions. Thus, a publication intended to take stock of legislative activities in a given period can be the subject of a great interaction, but extremely critical. Irony, sarcasm, complaints and even name-calling against the institution and the political actors are a daily part of the activity of managing the profiles of assemblies. 
Deepening the analysis and monitoring of citizens' response can be a strategy to address the hostile environment to political institutions conformed by social media. However, the extensive and in-depth study of this dynamics of engagement through platforms, in addition to offering possibilities for action to managers, can allow researchers to understand how political activities are conforming in this digital environment. And in this sense, lead to a better understanding of politics in contemporary societies.

In agreement with Leston-Bandeira (2014), it is worth mentioning that different tools may be appropriate to different elements of the engagement process. That is, the process is not exhausted on social media platforms, but is achieved by all initiatives of contact and communication with society carried out by parliaments. Included in this are the different actions that do not use digital media, as already mentioned.

Remembering that strategic planning has been carried out by the ALMG team for at least a decade, Marques Júnior (personal communication, 16 October 2018) points out that the Strategic Map 2010-2020 brings citizen recognition as the strategic target for ALMG's work. "Who do we want to be better at than? Our obligation is with the citizen who is represented here", he defends. The manager also informs that one of the purposes of the planning was exactly the improvement in the relationship with society. "How to effectively serve the citizen? Is it just the performance of the deputy that reflects to the citizen?" he asks.

The use of such tools with informative intentions is essential for the functioning of contemporary parliaments, but it is not enough for effective engagement. It seems to be a fundamental issue, which indicates a point of consensus among managers and researchers who analyze the use of social media by parliaments. For this, other dimensions of this action need to be taken into account and put into practice, which demands political will and direction of material and human resources for the activity.

Cristiane Brum Bernardes (cristiane.bernardes@ camara.leg.br) is a Professor at the Professional Master's Degree in Legislative Affairs at CEFOR and has a PhD in Political Science from IESP/UERJ.

\section{References}

Amaral, M.S., 2016. Congresso no Twitter: parlamentares e partidos políticos em 140 caracteres. Tese de doutorado. Salvador: Universidade Federal da Bahia (UFBA).

Almeida, H.N., 2017. Representantes, representados e mídias sociais: mapeando o mecanismo de agendamento informacional. Tese de doutorado. Belo Horizonte: Universidade Federal de Minas Gerais (UFMG).

Araújo, R., Travieso-Rodríguez, C. \& Santos, S.R.O., 2017. Comunicação e Participação Política no Facebook: análise dos comentários em páginas de parlamentares brasileiros. Informação \& Sociedade: Estudos, 27(2), pp.279-290.

Barros, A.T., Bernardes, C.B. \& Rodrigues, M.R., 2015. O Parlamento brasileiro e as novas mídias: balanço da experiência recente da Câmara dos Deputados. In A. Sathler \& R. Braga. (orgs.). Legislativo Pós-1988: reflexões e perspectivas. Brasília: Câmara dos Deputados, Edições Câmara, pp.183-221.

Barros, A.T., Bernardes, C.B. \& Rodrigues, M.R., 2016. Brazilian Parliament and digital engagement. The Journal of Legislative Studies, 22(4), pp.540-558. DOI: 10.1080/13572334.2016.1235331

boyd, D.M. \& Ellison, N.B., 2008. Social network sites: definition, history, and scholarship. Journal of Computer-mediated Communication, 13(1), pp.210-230. DOI: 10.1111/j.1083-6101.2007.00393.x

Braga, S.S., 2008. Podem as TICs auxiliar na institucionalização das Democracias? Um estudo sobre a informatização dos Órgãos legislativos na América do Sul e no Brasil. Brasília: Editora Plenarium.

Braga, S.S., 2013. O Uso das Mídias Sociais é Um Bom Preditor do Sucesso Eleitoral dos Candidatos? Uma análise das campanhas on-line dos vereadores das capitais das regiões sul, sudeste, e nord-este do Brasil no pleito de outubro de 2012. Revista Política Hoje, 22(2), pp.125-148.

Braga, S.S. \& Carlomagno, M.C., 2018. Eleições como de costume? Uma análise longitudinal das mudanças provocadas nas campanhas eleitorais brasileiras pelas tecnologias digitais (1998-2016). Revista Brasileira de Ciência Política, s/v(26), pp7-62. DOI: 10.1590/0103-335220182601 
Braga, S.S. \& Cruz, L.C., 2012. Elites parlamentares e novas tecnologias: um estudo sobre o uso da internet pelos deputados estaduais brasileiros da $16^{\text {a }}$ legislatura (2007-2011). Working papers/textos para discussão, n.4. Curitiba: Observatório de Elites Políticas e Sociais do Brasil/Núcleo de Pesquisa em Sociologia Política Brasileira/Universidade Federal do Paraná.

Carlomagno, M.C., Braga, S.S. \& Sampaio, R.C., 2018. Respondem os políticos a questionamentos dos eleitores? Um experimento controlando os incentivos de mensagem, período e meio. Opinião Pública, 24(2), pp.328-364. DOI: $10.1590 / 1807-01912018242328$

Chadwick, A., 2009. Web 2.0: New Challenges for the Study of E-Democracy in an Era of Informational Exuberance. I/S: Journal of Law and Policy for the Information Society, 5(1), pp.9-42.

Contreiras, P., 2012. Deputadas Parlamentares e Redes Sociais - O Mito das Redes como Facilitadoras de Proximidade entre os Políticos e os Cidadãos. Media \& Jornalismo, s/v(21), pp.145-158.

Enli, G.S. \& Skogerbø, E., 2013. Personalized Campaigns in Party-Centred Politics. Twitter and Facebook as arenas for political communication. Information, Communication \& Society, 16(5), pp.757-774.

Gomes, W., 2011. Participação política online: questões e hipóteses de trabalho. In R.C.M. Maia, W. Gomes, \& F.P.J.A. Marques (orgs.). Internet e participação política no Brasil. Porto Alegre/RS: Sulina, pp.19-45.

Gomes, W., 2016. 20 anos de política, Estado e democracia digitais: uma "cartografia” do campo. In S.P. Silva, R.C. Bragatto \& R.C. Sampaio (orgs.). Democracia digital, comunicação política e redes. Teoria e prática. Rio de Janeiro: Folio Digital, Letra e Imagem, pp.39-76.

Griffith, J. \& Leston-Bandeira, C., 2012 How are Parliaments Using New Media to Engage with Citizens? The Journal of Legislative Studies, 18(3), pp.496-513. DOI: 10.1080/13572334.2012.706058do

Jensen, J.L., 2013. Political participation online: the replacement and the mobilisation hypothesis revisited. Scandinavian Political Studies, 36(4), pp.347-364. DOI: 10.1111/1467-9477.12008

Júlio Neto, G.A., 2019. Desafios da comunicação pública face aos fluxos comunicacionais: Um estudo sobre a TV Assembleia/ES. In XXIV Congresso de Ciências da Comunicação na Região Sudeste. Vitória/ES.

Lemos, C.R.F., Barros, A.T. \& Bernardes, C.B., 2016. Public Communication in the Brazilian Congress: The News Agency and TV Station of the Chamber of Deputies. Latin American Research Review, 51(4), pp.202-224. DOI: 10.1353/lar.2016.0056

Leston-Bandeira, C., 2007. The impact of the internet on parliaments: a Legislative Studies framework. Parliamentary Affairs, 60(4), pp.655-674. DOI: 10.1093/pa/gsm040

Leston-Bandeira, C., 2012. Parliaments' Endless Pursuit of Trust: Re-focusing on Symbolic Representation. The Journal of Legislative Studies, 18(3-4), pp.514-526. DOI: 10.1080/13572334.2012.706059

Leston-Bandeira, C., 2014. The pursuit of legitimacy as a key driver for public engagement: The European Parliament case. Parliamentary Affairs, 67(2), pp.415-436. DOI: 10.1093/pa/gss050

Leston-Bandeira, C., 2016. Why Symbolic Representation Frames Parliamentary Public Engagement. British Journal of Politics and International Relations, 18(2), pp.498-516. DOI: 10.1177/1369148115615029

Leston-Bandeira, C \& Bender, D., 2013. How deeply are parliaments engaging on social media? Information Polity, 18(4), pp.281-297. DOI: 10.3233/IP-130316

Lucinda, K., 2016. Comunicação Pública via Mídias Sociais: Estudo de caso da Assembleia Legislativa do Estado de Santa Catarina. Trabalho de conclusão de curso de graduação. Florianópolis: Universidade Federal de Santa Catarina (UFSC).

Lucinda, K. \& Bertasso, D., 2017. Comunicação Pública via Mídias Sociais: estudo de caso da Assembleia Legislativa do Estado de Santa Catarina. In VII Congresso da Associação Brasileira de Pesquisadores em Comunicação e Política (VII COMPOLÍTICA). Porto Alegre/RS.

Mendonça, R.F., 2016. Deliberação on-line. Uma avaliação de algumas propostas de mensuração. In R.F. Mendonça, M.A. Pereira \& F. Filgueiras. (orgs.). Democracia digital. Publicidade, instituições e confronto político. Belo Horizonte: Editora UFMG, pp.259- 284.

Mendonça, R.F \& Pereira, M.A., 2016. Dilemas na apropriação das TICs pela ALMG. Uma análise sobre a percepção dos gestores. In R.F. Mendonça, M.A. Pereira \& F. Filgueiras (orgs.). Democracia digital. Publicidade, instituições e confronto político. Belo Horizonte: Editora UFMG, pp.189-216.

Mendonça, R.F, Pereira, M.A. \& Filgueiras, F., 2016. Democracia digital. Publicidade, instituições e confronto político. (orgs.). Belo Horizonte: Editora UFMG.

Miola, E., Marques, F.P.J., Cardoso, N.P. \& Mancio, C.R.P., 2018. Campanhas eleitorais no Facebook: usos na eleição municipal de Curitiba em 2016. Conhecer: debate entre o público e o privado, 8(21), pp.78-97. DOI: 10.32335/2238-0426.2018.8.21.1057.

Santos, J.G. \& Bernardes, C.B, 2020. Uso do YouTube por Parlamentos brasileiros: temáticas e comentadores. In III Congresso do INCT.DD - Democracia, Governo e Política Digitais. Online.

Silva, S.P., Sampaio, R.C. \& Bragatto, R.C., 2016. Concepções, debates e desafios da democracia digital. In S.P. Silva, R.C. Bragatto \& R.C. Sampaio (orgs.). Democracia digital, comunicação política e redes. Teoria e prática. Rio de Janeiro: Folio Digital, Letra e Imagem, pp.17-37.

Tavares, D.N., 2014. Nos esconderijos da virtualidade: o "Homem Cordial" nas vinculações via redes sociais on-line entre senadores e cidadãos. Dissertação de Mestrado. Brasília: Faculdade de Comunicação, Universidade de Brasília.

Tavares, N.D. \& Quiroga, T., 2015. O reforço do "homem cordial" nas conexões entre senadores e cidadãos nas redes sociais online. Revista do Instituto de Estudos Brasileiros, s/v(60), pp.110-128.

Williamson, A., 2013. Social Media Guidelines for Parliaments. Geneva: Inter-Parliamentary Union. 
Zémor, P., 1995. La Communication Publique. Que sais-je? Paris: PUF.

\section{Others Sources}

IBGE. 2018. Projeções da População: Brasil e unidades da federação: revisão 2018. Available through: <https://biblioteca.ibge.gov.br/visualizacao/livros/liv101597.pdf>. Accessed at: 25 oct. 2019.

PNAD - Pesquisa Nacional por Amostra de Domicílios Contínua. 2017. Acesso à Internet e à televisão e posse de telefone móvel celular para uso pessoal. Available through: <https://biblioteca.ibge.gov.br/index.php/biblioteca-catalogo?view=detalhes\&id=2101631>. Accessed at: 13 nov. 2019.

Engajamento público e o uso institucional do Facebook nas assembleias legislativas da Região Sudeste

PALAVRAS-CHAVE: Poder Legislativo; Assembleia Legislativa; Facebook; Redes Sociais; Engajamento Público.

RESUMO Introdução: Em um contexto de intensificação da interatividade, da hiperconectividade e da mobilidade, e ampliação das possibilidades de contato entre instituições legislativas e cidadãos por veículos digitais, este estudo analisa, comparativamente, como as quatro assembleias legislativas da Região Sudeste do Brasil utilizam os perfis institucionais criados no Facebook. O objetivo é compreender como o processo de engajamento público, conforme conceituado por Leston-Bandeira (2014), está sendo realizado pelas casas legislativas nessa plataforma. Materiais e Métodos: A coleta de dados empíricos sobre os perfis das assembleias legislativas de São Paulo, Minas Gerais, Rio de Janeiro e Espírito Santo foi realizada entre agosto de 2018 e outubro de 2019. Foram aplicadas as seguintes técnicas: 1) entrevistas em profundidade com os gestores da comunicação digital das casas e 2) análise comparativa das publicações e dos comentários no Facebook no período entre agosto de 2018 e janeiro de 2019. Os dados dos perfis foram coletados por meio do aplicativo Netvizz e analisados posteriormente a partir do Excel. As entrevistas foram realizadas entre agosto e dezembro de 2018 e em outubro de 2019 de forma presencial ou via internet (Skype e vídeo do WhatsApp). Resultados: Os dados comparativos revelam que o perfil @assembleiademinas fez um uso mais intenso do Facebook no período analisado, apesar de ter menos seguidores do que os perfis da ALERJ e da ALESP. Para além de postar mais, o perfil da ALMG alcançou mais interações dos cidadãos, especialmente por meio das reações a algumas postagens feitas em outubro e dezembro de 2018. Das quatro assembleias analisadas, o perfil da ALES é o que teve o menor alcance quantitativo, em número de usuários que interagem, tanto em relação às reações, quanto aos comentários. ALMG tem o perfil que recebeu mais reações por postagem, enquanto a ALESP recebeu mais comentários por post no período. Discussão: A conclusão mais geral é que as quatro casas legislativas analisadas não conseguem realizar o monitoramento das contribuições dos internautas e promover uma interação mais dialógica com eles, ficando centradas nos níveis de informação, compreensão e identificação do processo de engajamento público. Há, portanto, uma dificuldade de incluir os aspectos da participação e da intervenção na decisão política nas dinâmicas das mídias sociais. Em última medida, ao não aproveitarem o potencial dialógico das redes, as assembleias legislativas desperdiçam oportunidades de contato com o cidadão e ampliam seu distanciamento da sociedade.

This is an Open Access article distributed under the terms of the Creative Commons Attribution Non-Commercial License which permits unrestricted non-commercial use, distribution, and reproduction in any medium provided the original work is properly cited. 


\section{Appendix 1 - List of Interviewees}

Abend, C., 2018 (3 Set). Personal communication as director of communications of ALERJ [informal telephone conversation].

Albani, L., 2019 (25 Set). Personal communication as manager of advertising, design and social media of ALES [Whatsapp video interview].

Coelho, A., 2018 (12 Nov). Personal communication as deputy-director of communication of ALERJ [Whatsapp video interview].

Farage, F., 2018 (15 Aug). Personal communication as general manager of press and dissemination and manager of the project: ALMG Digital Presence [in-person interview].

Marques Júnior, A.M., 2018 (16 Oct). Personal communication as director of planning and coordination of ALMG [in-person interview].

Menezes, D.S.M., 2018 (14 Nov). Personal communication as manager of institutional relations of ALMG [in-person interview].

Sá, M., 2019 (24 Oct). Personal communication as editor-in-chief of the communication department of ALESP [Whatsapp video interview].

Terra, A.C.U., 2018 (16 Oct). Personal communication as manager of digital media of ALMG [in-person interview].

Tiriba, D., 2018 (28 Set). Personal communication as journalist and designer responsible of content production for social media at ALERJ [in-person interview].

Vieira, T., 2018 (28 Set). Personal communication as coordinator of the centre of marketing and special projects of ALERJ [in-person interview].

\section{Appendix 2 - Interview on Social Media}

1. What are the social media currently maintained by the Assembly?

2. Since when does the House maintain profiles on social media?

3. How are these platforms used daily?

4. What are the objectives of using social media for the institution?

5. What is the structure for performing this activity: is there a specific sector responsible for it?

6. Who does the posts?

7. How many people work with this in the House?

8. What kind of content is posted on social media?

9. Do you have any kind of monitoring? How is it done? By whom?

10. Have there been any changes to this activity (team, resources, type of posts, etc.) in the last year?

11. What are the advantages of using social media for the House?

12. What are the challenges faced by the team in this activity? 